\author{
Ewout A. Kouwenhoven \\ Jan N. M. IJzermans \\ Ron W. F. de Bruin
}

\section{Etiology and pathophysiology of chronic transplant dysfunction}

Received: 2 August 1999

Revised: 11 April 2000

Accepted: 27 June 2000

E. A. Kouwenhoven - J. N. M. IJzermans

R.W.F. de Bruin

Department of Surgery,

Erasmus University Rotterdam,

P.O. Box 1738, 3000 DR Rotterdam,

The Netherlands

R. W.F. de Bruin (

Laboratory for Experimental Surgery and Oncology,

Erasmus University Rotterdam,

PO Box 1738, 3000 DR Rotterdam,

The Netherlands

e-mail: debruin@heel.fgg.eur.nl

Tel.: + 31-10-408-7761

Fax: + 31-10-408-9471

\begin{abstract}
Chronic transplant dysfunction (CTD) is the predominant cause of late graft failure. The common histopathological feature in all transplanted organs is intimal hyperplasia accompanied by organ specific lesions. The knowledge about CTD is incomplete, and there is no therapy to prevent or treat it. This review describes the current knowledge on the etiology of CTD, with emphasis on kidney transplants, and postulates a pathophysiologic route through which CTD may develop.
\end{abstract}

Keywords Chronic transplant dysfunction · Etiology · Pathophysiology $\cdot$ Review

\section{The problem of chronic transplant dysfunction}

Since it was first shown in 1954 that successful transplantation of a healthy kidney could completely rehabilitate an individual with renal failure, transplantation of several organs has become an increasingly successful medical treatment for patients with end-stage organ failure. In 1998, in the Eurotransplant area alone, more than 3000 kidneys, 750 hearts, about 1000 livers, 230 lungs, and about 100 pancreas from cadaveric donors were transplanted [9]. Worldwide, 56 intestinal transplantations were performed in 1996 [70]. The shortterm results after clinical organ transplantation have improved progressively. This is principally due to refinements in tissue typing, advancements in organ preservation, operative techniques and ancillary care, more effective immunosuppressive agents, and better monitoring after engraftment. For example, one year survival of cadaveric kidneys has increased from approximately $50 \%$ by the end of the $1960 \mathrm{~s}$, to about $85 \%$ nowadays [67], and for living-related kidneys from $80 \%$ to

Despite improving early results, however, it has become clear that clinical transplantation has not achieved its goal as a long-term treatment. For the period beyond one year, the annual rate of graft loss has changed less since the beginning of the experience. The half-life of cadaveric kidney allografts, for instance, has remained consistent at 7.5-9.5 years, although the latest United States Renal Data System (USRDS) data suggest that half-life of first cadaveric kidney grafts is improving (Figure 1) $[68,146]$. Similarly, the half-life beyond the first year of heart transplants is 10.5 years [146]. Other organ transplants generally show comparable results, with exception of the liver, which shows more favourable long-term results $[10,98]$. 
Fig. 1 Cadaveric kidney graft survival for first transplants, 1986-1995. Rates adjusted for sex, race, and cause of ESRD. Derived from: United States Renal Data System 1999 Annual Data Report

\section{Graft survival (\%)}

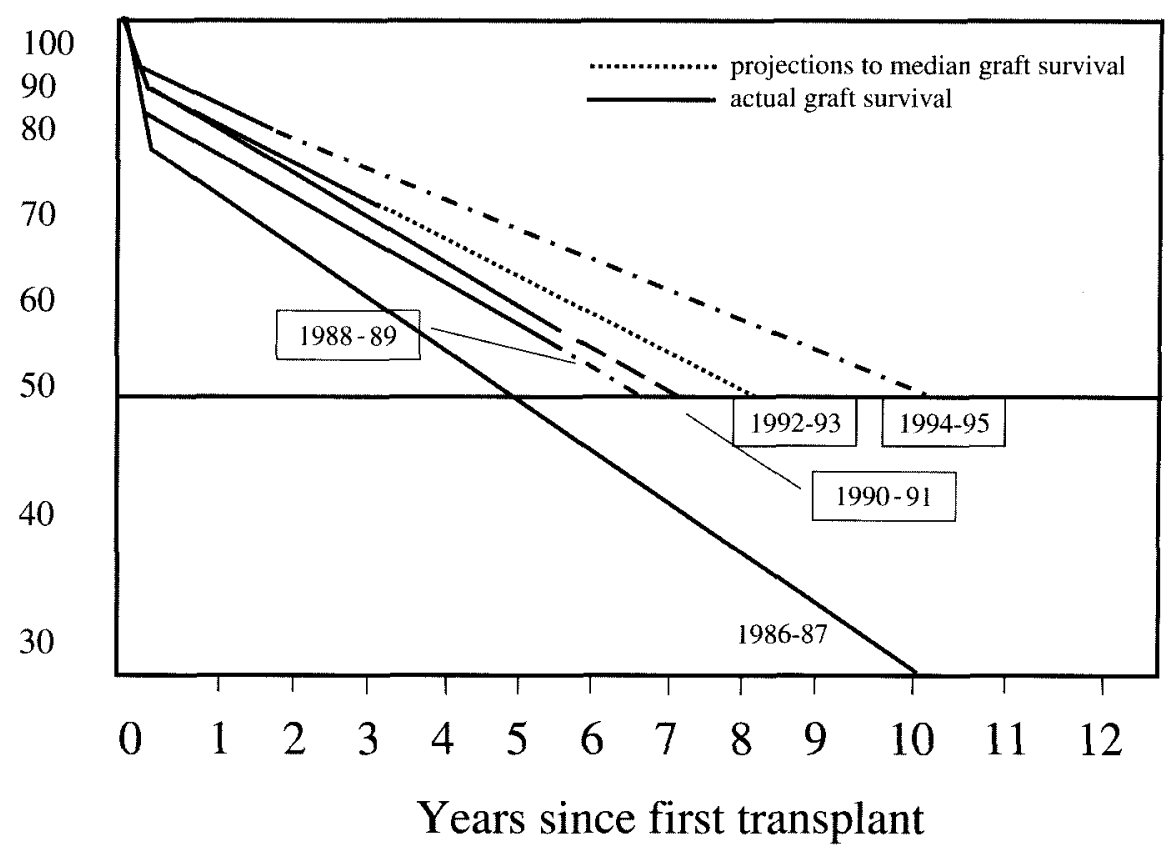

Chronic transplant dysfunction (CTD) is the most important, single cause of late graft deterioration and failure. Kidney graft loss is in $35 \%-58 \%$ due to CTD [53], more than $70 \%$ of lung allografts had CTD 5 years post-transplantation [166]; more than $50 \%$ of the heart transplants had severe coronary arteriosclerosis at five years [222, 231]; and about $9-26 \%$ of graft loss of liver transplants was due to CTD $[1,14,194]$. Moreover, a significant number of functioning grafts is lost due to death of the recipient. There is still no treatment to inhibit or prevent CTD, and a conclusive therapeutic strategy is not within hand's reach since its etiology and pathophysiology are poorly known.

\section{Definition of chronic transplant dysfunction: functional and histopathological characteristics}

CTD is a phenomenon in solid organ transplants displaying a gradual deterioration of graft function months to years after transplantation, eventually leading to graft failure, and which is accompanied by characteristical histological features. Clinically, CTD in kidney grafts manifests itself as a slowly progressive decline in glomerular filtration rate, usually in conjunction with proteinuria and arterial hypertension [150]. In heart transplants, CTD presents itself with congestive heart failure, acute infarction, arrythmias and, most dramatically, as sudden death [63]. The diagnosis of liver CTD should be based upon clinical evidence of chronic liver disease consisting of persistent enzyme abnormalities, elevated bilirubin, diminished synthesis of protein and blood clotting factors $[46,60]$. Intractable diarrhoea and weight loss are the accompanying symptoms in intestinal transplants with CTD [191].

The cardinal histomorphological feature of CTD in all parenchymal allografts is fibroproliferative endarteritis [2]. The vascular lesion affects the whole length of the arteries in a patchy pattern. There is concentric myointimal proliferation resulting in fibrous thickening and the characteristic 'onion skin' appearance of the intima in small arteries [2]. Other findings include endothelial swelling, foam cell accumulation, disruption of the internal elastic lamina, hyalinosis and medial thickening, and presence of subendothelial T-lymphocytes and macrophages [91]. In addition, a persistent focal perivascular inflammation is often seen. Although intimal hyperplasia is very specific for CTD, the diagnosis of CTD in biopsies of allografts is frequently based on other, less specific abnormalities, since intimal hyperplasia is very patchy and affects mainly arteries larger than those seen in biopsies.

In addition to vascular changes, kidneys undergoing CTD also show interstitial fibrosis, tubular atrophy and glomerulopathy. Chronic transplant glomerulopathy duplication of the capillary walls and mesangial matrix increase - has been identified as a highly specific feature of kidneys with CTD [196]. Less specific lesions are glomerular ischemic collapse, tubular atrophy, and interstitial fibrosis. Furthermore, peritubular capillary 
Table 1 Risk factors for CTD

\begin{tabular}{ll}
\hline Alloantigen specific factors & Non-alloantigen specific factors \\
\hline Histoincompatibility & Ischemia \\
Acute rejection episodes & Brain death \\
Suboptimal immunosup- & \\
pression & Infection \\
Non-compliance & Hyperlipidemia \\
Anti-donor antibodies & Hypertension \\
& Age \\
& Gender \\
& Race \\
& Size \\
\hline
\end{tabular}

basement splitting and laminations are associated with late decline of graft function [136]. The criteria for histological diagnosis of CTD in kidney allografts are internationally standardised in the BANFF scheme for Renal Allograft Pathology [195].

Until now, such typically functional and histological changes of allografts are often diagnosed as 'chronic rejection'. However, the designation 'rejection' presumes a host alloimmune responsiveness to be basis for these changes. Since there are indications that non-alloimmune mediated factors involved in organ transplantation can cause similar functional and histopathological changes, calling the whole process chronic rejection is not satisfactory. As long as the result - dysfunction and characteristic histological changes - cannot be exclusively attributed to an alloimmune-mediated pathway, it is recommended to name the process CTD, leaving any causative factor out of consideration.

\section{Etiology of chronic transplant dysfunction}

In 1963, Porter et al reported four human cadaveric kidney allotransplants in which striking obliterative vascular lesions developed a few months after transplantation [158]. All patients had experienced early episodes of acute rejection, and the subsequent vascular lesions were thought to have an immunological basis. These cases suggested that the process of allograft rejection can evolve from early acute cellular infiltration of the engrafted organ to a more chronic process, ultimately resulting in intimal arterial thickening, with interstitial fibrosis. However, to the present day the cause of CTD remains ill defined. Two working hypotheses are proposed to understand the process: 1) the phenomenon leading to CTD is the result of an ongoing host alloimmune response. 2) Non-alloimmune responses-to-injury, such as ischemia, can cause or aggravate the process.

\section{Alloantigen-specific factors}

Several data indicate that CTD is the result of the recipient's immune response to incompatible donor tissue antigens. In this view, the relationships between the following identified risk factors and CTD all reflect an alloimmunologic mechanism: 1) Histoincompatibility, 2) Acute rejection, 3) Suboptimal immunosuppression/ non-compliance, and 4) Anti-donor specific antibodies. Antigenic disparity in humans between donor and host is associated with the occurrence of CTD, as demonstrated in kidney, heart, and lung transplant studies. Long-term graft survival appeared to be strongly correlated with the degree of histocompatibility matching between donor and recipient $[67,89,146,194,214]$. Cadaveric kidneys with zero HLA-mismatches have a half-life of 13.2 years compared to 7.0 years in grafts with six-allelic mismatches [146]. Interestingly, some large unicentre studies are unable to demonstrate the benefit of histocompatibility matching for the development of CTD in kidneys and hearts, independently of the effect of acute rejection [88]. It is presently unclear whether matching directly affects the development of CTD or whether this results from a decreased incidence of acute rejection episodes $[20,38,155,193]$.

Graft survival studies from uni- and multicentres alike show a strong correlation between acute rejection episodes and the lifespan of a graft [115, 125, 147, 224]. For instance, Matas et al [125] showed in a group of 278 cadaver kidney graft recipients that a single rejection episode in the first post-transplant year reduces the estimated graft half-life from 33 years to 22 years, whereas multiple rejections or a single rejection after the first year decreases the half-life to less than 5 years. Several retrospective analyses of organ grafts with CTD demonstrate that acute rejection is strongly related to the development of CTD in all types of organ transplants [17, $28,57,88,105,101,195]$. Basadonna et al reported that in a cohort of 205 cadaveric renal transplant recipients, the incidence of biopsy-proven CTD was $0 \%$ in the 109 patients without acute rejection, $36 \%$ in the 69 patients with an acute rejection within the first 2 months after transplantation $(P<0.001)$, and $63 \%$ in the 27 patients with acute rejection 60 days after transplantation $(P<0.001)$ [45]. Other clinical studies have corroborated and refined these findings: The onset, frequency, and severity of an acute rejection episode are independent risk factors for CTD [19, 57, 204, 224]. Acute rejections with complete functional recovery do not have a deleterious effect on the long-term outcome [39, 226], whereas an increased baseline serum creatinine level after treatment of an acute rejection episode is associated with CTD [92, 147] In addition, the vascular type of acute rejection appears to be a stronger risk factor for the occurrence of CTD than interstitial rejection [223]. Experimental studies in kidney-, heart-, and lung trans- 
plantation models confirm these clinical observations $[86,90,141,232,233,235]$. Nonetheless, acute rejection is not a prequisite for CTD: patients may also develop CTD without prior acute rejection episodes [41, 45, 54]. Reviewing the literature, it can be stated that at present, acute rejection is the most consistently identified clinical risk factor for the occurrence of CTD.

A low dose of maintenance Cyclosporine (CsA) medication in some clinical studies has been associated with CTD [6, 194, 177], but not in others [68]. At 5 years post-transplantation, the percentage of recipients who were free of CTD as demonstrated by biopsy was $86 \%$ for those using CsA $>5 \mathrm{mg} / \mathrm{kg}$ per day versus $77 \%$ for those on $<5 \mathrm{mg} / \mathrm{kg}$ per day [6]. Additional evidence that CTD may be related to inadequate immunosuppression was provided by the histopathological studies of Isoniemi et al [96]. They found that CTD-lesions were less apparent in patients given protocols of tripleversus double-dose immunosuppressive therapy. Experimentally, we and others have demonstrated that in the rat aortic allograft model, both high dose CsA as well as other immunosuppressive agents were able to prevent the inflammatory response, and concomitantly inhibit the generation of intimal lesions during the 4weeks follow-up period $[65,103,199]$. However, in man it would be impossible to maintain high doses of immunosuppressants on the long-term, because of the associated toxic side effects [203].

Noncompliance also indicates that CTD may result from inadequate immunosuppression $[24,51,217]$. In a study by the Minneapolis group, $34 \%$ patients were noncompliant, and this was associated with late deterioration of graft function [124].

Many studies have shown that following transplantation, the majority of patients produce antibodies $[49,75$, $99,121,122,149,154,165,168,192,202]$. Both, preformed antibodies reactive against donor tissue, and antibodies produced after transplantation against HLA class I antigens and against tissue, (endothelial cells, smooth muscle cells) are found. A correlation between antibodies and CTD, however, is not consistently found $[45,49,54,58,90,149,166,179]$. No difference in panel-reactive antibody levels was found between those of patients whose grafts were still functioning, versus those of patients who lost their graft due to CTD [59, 179] Likewise, Hosenpud et al found no differences in the presence of IgM antibodies against endothelial cells of kidney grafts with or without CTD [90]. Other investigators, however, observed significantly more anti-donor reactivity against both HLA class I and II in sera of patients with biopsy-proven CTD in kidneys (94.4\%) than in sera of patients with a normal functioning graft $(12.8 \%)$ [144]. In $70 \%$ of the liver allografts with CTD, patients had non-HLA anti-smooth muscle and anti-nucleus antibodies, which were not present in patients with a healthy liver transplant [77].
Experimentally, Paul et al demonstrated IgG antibodies against the glomerular and tubular basement membrane, the mesangial cell, and endothelial cell antigens in sera of rats with a kidney allograft with CTD, whereas such antibodies were not found in sera from animals that had received a syngeneic graft $[85,151]$. In other experimental models of CTD, the presence of antibodies was noted in areas with intimal hyperplasia $[64,78]$.

\section{Non-alloantigen associated factors}

In the late 1980 -ies, attention was redrawn to the fact that in the pre-immunosuppression era even human kidney transplants between identical twins developed late morphological changes. Two-thirds of these kidney isografts developed glomerular lesions between 2 months and 16 years post-transplantation, which were classified as a recurrence of the original disease, glomerulonephritis [69]. Two of these grafts with glomerular lesions developed in a later stage additional vascular lesions. It was also suggested that such changes observed in human renal isografts might have been a consequence of the transplantation injury per se [42]. Nowadays, surgical injury and other, non-alloimmune specific factors related to the donor and the graft have been associated to the development of CTD [54, 104, 220]. These risk factors include: ischemia, brain death, viral infections, hyperlipidemia, hypertension, age, gender, race, and the amount of functional tissue.

In clinical transplantation it is still unclear if ischemia participates in the development of CTD. While some studies reported that prolonged cold ischemia reduces graft survival $[38,67,218]$, others found no correlation $[153,155]$. For instance, the UNOS registry showed that preservation for $>24$ hours significantly impaired late kidney graft survival rates compared to cold ischemic times between 0-24 h [67]: In cardiac transplants, a prolonged ischemic time was a risk factor for transplant arteriosclerosis [13]. Experimental transplant studies have demonstrated that ischemia per se can cause CTD-like lesions in the absence of allogenicity [225]. We [104], and others [220] have demonstrated that rat kidney isografts develop the same functional and morphological changes as allografts, including vasculopathy, albeit over a much longer time interval. These changes appeared to be triggered mainly by ischemia. Similarly, on the long-term, syngeneic aorta and heart transplants develop intimal hyperplasia, in which the degree of intimal hyperplasia correlates with the duration of the ischemia period [178, 227]. Nonetheless, it is much less clear whether the length of the ischemic period plays a role in the onset of CTD in allografted organs. While Hayry's group showed that in renal allografts a cold ischemic time of $60 \mathrm{~min}$ led to in- 
creased intimal proliferation and glomerulosclerosis, compared to kidneys subjected to 30 min cold ischemia [236], in heart and aortic allografts the duration of the cold ischemic period did not have an influence on the degree of CTD [8, 101, 227].

It has also been suggested that in allografts the effect of ischemia on CTD is indirect by predisposing for acute rejection. Organ grafts with prolonged cold ischemia or with delayed graft function experience more often an early acute rejection episode than grafts that functioned immediately $[72,73,145,188,218]$. We showed that, following $24 \mathrm{~h}$ of cold ischemia, increased numbers of $\mathrm{CD}^{+}$cells and macrophages infiltrated the kidney grafts, compared to non-ischemic controls. Importantly, ischemic grafts still showed significantly increased numbers at one year post-transplant. Histologically, these grafts showed more glomerulopathy and intimal hyperplasia than non-ischemic controls [104]. These data presume a direct effect of ischemia on long-term outcome.

The striking divergence in clinical long-term results between kidney grafts from cadavers and those from living-related and unrelated donors [212], has drawn attention to the health of an organ before procurement. The hypothesis has been put forward that brain death activates surface molecules on peripheral organs via cytokines. In brain death donors, increased serum cytokine levels are found before organ procurement [161]. In experimental models of brain death, peripheral organs show increased endothelial cell activation $[87,208]$ and a more accelerated tempo of acute rejection in organs from brain dead animals is observed [160, 229]. The relevance for CTD still has to be proved.

While infection with cytomegalovirus (CMV) has shown to be related to CTD in cardiac-, liver-, and lung transplantation [71, 105, 108, 128, 143], its association with CTD in kidney transplants is not yet clear. A multivariate analysis on risk factors for CTD performed on 675 renal allograft recipients showed no difference in the incidence of CMV infection in patients who did or did not loose their grafts to CTD [122]. Experimentally, CMV infection has been identified as promotor of CTD in aorta, kidney and heart transplants [110, 111, 235]. CMV infection directly affects intercellular adhesion molecule-1 (ICAM-1) expression on endothelial cells, $[159,234]$ and induction of MHC class II antigens is observed, together with a prolonged and increased acute cellular infiltration of $\mathrm{T}$ cells and macrophages [109].

Hyperlipidemia is a controversial risk factor for allograft arteriosclerosis $[18,52,180]$. The relevance of hyperlipidemia in animal transplant arteriosclerosis models has also been a matter of controversy $[3,7,48$, $56,133,211]$.

Systemic hypertension in clinical kidney and heart transplants is associated with CTD [30, 148, 157, 162]. In heart transplant recipients, hypertension was associ- ated with an earlier onset of CTD [162]. In renal allograft recipients, hypertension is a common event $(75 \%)$, although its role as a causative factor or a consequence of renal dysfunction is difficult to define since a vicious circle is created where the worsening of one parameter leads to the worsening of the other [163]. Experimental studies showed that systemic hypertension accelerates CTD in kidney allografts [106], whereas antihypertensive drugs inhibited the progression of chronic allograft dysfunction [22]. Similarly, in rat aortic transplants, hypertension was associated with a significant increase of intimal thickness, whereas ACE-inhibition was able to decrease systolic blood pressure by $30 \%$, and concomitantly reduce intimal lesions by $40 \%$ [134].

Donor age is a controversial risk factor. Some investigators have found that grafts from donors over 60 years of age are associated with poorer survival rates [33, 79, 123]. Cardiac transplants from an older aged donor had an earlier onset of CTD $[23,40]$.

In male recipients, solid organ grafts appeared to be more vulnerable for the development of CTD. In cardiac allografts, the onset of arteriosclerosis was earlier in males than in females [40] and the prevalence of CTD was reported to be higher in male- than in female recipients: $30 \%$ versus $50 \%$ free of coronary artery disease at 5 years $(P=0.01)[129]$. The UNOS Transplant Registry reported a similar observation for kidney grafts [67]. Experimental studies have corroborated these observations: In rat syngeneic aorta transplants, female gender protects against myointimal hyperplasia [59]. This gender effect could reflect oestrogen. Oestrogen protects against cardiovascular disease, and it has been demonstrated that oestradiol effectively inhibits transplant arteriosclerosis in experimental models $[32,116$, 175].

Long-term survival of cadaveric renal transplants appeared to be related to race: Five-year graft survival rates were $66 \%$ for Asians, $61 \%$ for Caucasians and Hispanics, and $47 \%$ for Black recipients [100]. Black recipients of heart transplants developed CTD earlier than non-blacks [40]. The absence of the Duffy antigen Receptor for Chemokines on erythrocytes in African Americans seems an important risk factor for the development of CTD [44].

A risk factor reserved to the kidney is the contribution of reduced numbers of nephrons to the progression of CTD. In non-transplant models in the rat, it is well established that kidneys with significantly reduced numbers of nephrons, such as in the 'remnant kidney model', develop glomerulosclerosis, tubular atrophy, and interstitial fibrosis in response to an increased workload of the remaining nephrons, i.e. hyperfiltration $[142,186]$. In a chronic kidney allograft model, Heemann et al demonstrated that reduction of renal mass led to earlier onset of CTD and shortened survival. Moreover, iso- 
grafts and non-transplanted, ablated kidneys having only $1 / 6$ of total mass experienced proteinuria in the same tempo as allografts, whereas $2 / 6$ or $3 / 6$ nephrectomized native and isografted kidneys had negligible damage [83]. Thus, the reduction of functioning renal mass accelerated the changes characteristic for CTD, and after a substancial reduction, hyperfiltration plays an overriding role in further deterioration [117]. Nonetheless, in clinical kidney transplantantion, the significance of a mismatch between donor nephron supply and functional metabolic demand of the recipient in the development of CTD is unclear. Poorer survival of grafts from very young, elderly, black, or female donors, compared to grafts from donors aged 15-55, non-black or from male donors has been ascribed to hyperfiltration damage [25]. None of these CTD-prone conditions, however, are uniformly found. Miles et al did not find that the donor kidney size was different in patients who lost their graft due to CTD compared with the kidney size of patients with stable function [135]. Others did not see differences in CTD between pediatric kidney recipients and adult-kidney recipients either [5]. Paired pediatric kidney transplantation did not improve renal function compared to small single pediatric kidneys [164].

\section{Pathophysiology of chronic transplant dysfunction}

As already outlined, CTD is characterized by morphological evidence of destruction of the transplanted organ [191]. The common denominator of all parenchymal organs is the development of intimal hyperplasia. Whether the parenchymal changes with fibrosis occurs secondarily to gradual arterial insufficiency and ischemia, or if they develop from ungoing subclinical host immunological attacks or other factors, remains undefined.

Immunohistochemistry of allografts with CTD has shown that $\mathrm{T}$ cells and macrophages are the predominant graft-invading cell types, with an excess of CD4 ${ }^{+}$ over $\mathrm{CD}^{+} \mathrm{T}$ cells $[4,47,50,82,104,176,191,198]$. Increased expression of adhesion molecules (ICAM-1, VCAM-1) [77, 114], and MHC antigens [81, 114] are seen in allografts with CTD. Also, complement and immunoglobulin deposits are seen in areas with intimal hyperplasia $[77,78,90,114]$. Little consistent information is available on the expression of growth-regulating factors and their receptors in organ transplants with CTD. An increased TGF- $\beta$ expression, however, is frequently found $[152,185,206]$.

The histologic lesions, including intimal hyperplasia, the infiltrating cells, upregulated adhesion molecules, and cytokines in organ transplants with CTD do not necessarily reflect an alloimmune-mediated response. As already mentioned, syngeneic transplants, ischemiaor mechanically-injured organs also show cell infiltra- tion, upregulation of cytokines and develop CTD-like lesions $[104,220,227]$. Notwithstanding, the development of the lesions occurs much more rapidly in allografts, suggesting that alloimmune responses play a role [104]. The most consistent clinical risk factor 'acute rejection' also indirectly indicates that an alloimmune response is involved in CTD and suggests that CTD is, for the main part, the result of insufficient immunosuppression. More evidence to support this hypothesis comes from experiments that have demonstrated that pretransplant immunizations with donor splenocytes accelerate CTD [41], whereas manipulations aimed at induction of tolerance delay the process $[36,187]$. In the following subparagraphs, we suggest the route through which a graft may develop CTD.

\section{Initial response-to-injury}

\section{Endothelial cell activation}

The specific adhesion of cells to other cells or to particular tissues is a basic function of cell migration and recognition. Under normal conditions, contact between leukocytes and vascular endothelium is random if both cell types are inactive and at rest, the cells touch vessel walls indiscriminately. In organ transplantation, the endothelial cells are activated by ischemia, surgical manipulation, and reperfusion injury, events inherent to the procedure. After ischemia and reperfusion, endothelial cells produce oxygen free radicals predominantly via the xanthine-oxidase pathway, which in vitro activate and damage the cells [21]. Upon activation, the endothelial cells retract and release increased amounts of the cytokines IL-1, IL-6, IFN- $\gamma$, TNF- $\alpha$, the chemokines IL-8, macrophage chemoattractant protein (MCP)-1, macrophage inflammatory protein (MIP)- $1 \alpha$ and MIP$1 \beta$, colony stimulating factors, and multiple growth factors such as, platelet derived growth factors (PDGF), insulin growth factor-1(IGF-1), transforming growth factor (TGF) $\beta$, and pro-thrombotic molecules (tissue factor, plasminogen activator inhibitor). This secretion enhances migration of neutrophils, monocytes/macrophages and $T$ lymphocytes to the site of injury [27]. The release of cytokines also leads to upregulation of adhesion molecules on the vascular endothelium [27, 62]. The proinflammatory cytokines IL-1 and TNF $\alpha$ induce the expression of the adhesion molecules $\mathrm{P}$ - and E-selectin on the endothelium [167, 230], by which circulating leucocytes begin to adhere via binding to their surface carbohydrates $[112,127,197]$. Leucocytes are then triggered by the chemokines released by the endothelium, which causes upregulation of the affinity of the $\beta_{2}$-integrin receptors LFA- 1 and MAC- 1 on their surface. This enables a permanent adherence of leucocytes to the endothelial adhesion molecules ICAM-1 
and VCAM-1 [118], the expression of which is induced by the released cytokines IL-1 $\beta, \operatorname{IFN} \gamma, \mathrm{TNF} \alpha[26,156]$. Activated complement also plays a role in the adhesion of neutrophils and monocytes to endothelium [16]. Finally, extravasation of leucocytes occurs to the extracellular matrix and graft tissue, presumably facilitated by activated complement $[209,229]$ and oxygen-free radicals that increase the permeability between endothelial cells [94]. The first cells that infiltrate the graft are neutrophils. They further aggravate the inflammatory response through release of oxygen-free radicals and inflammatory mediators, including platelet activatinglike factors and leukotrienes. Direct evidence that oxygen free radicals, adhesion molecules, and neutrophils play a role in the pathogenesis of CTD is shown by interference studies $[29,107,210]$. One recent study, for instance, revealed that carotid allografts from donor mice deficient in ICAM-1 had a $52 \%$ reduction of intimal hyperplasia compared to controls [183].

In addition to the increased expression of adhesion molecules on the endothelium, after reperfusion of a transplanted organ, a dramatic upregulaton of MHC class I and II antigens on the endothelium occurs [37, 93], which appears to be induced by release of cytokines IFN- $\gamma$, TNF- $\alpha$ and TNF- $\beta[74,181]$. Alterations in tissue density of MHC class II antigens are likely to influence the alloimmune response against the tissue [76]. Parenchymal cells are also activated after ischemia. In nontransplanted kidneys, MHC class I and II antigens are upregulated on the tubular epithelium $[93,189]$. Epithelial cells in lung autotransplants showed a mild expression of MHC class II after cold ischemia [181].

$\mathrm{CD}^{+}$T-lymphocytes infiltrate ischemic allografts, isografts and non-transplanted organs $[11,93,104$, 220]. In addition, $T$ cell associated cytokines, such as IFN $-\gamma$ and TNF- $\alpha$ are produced [93] and blockade of the C28-B7 costimulatory pathway decreased early influx of $\mathrm{T}$ cells and expression of $\mathrm{T}$ cell associated cytokines [207]. We showed that cyclosporine was able to overcome the deleterious effects of ischemia in syngeneic transplants with a concomitant decrease in infiltrating $\mathrm{CD}^{+} \mathrm{T}$-cells [104]. The role of $\mathrm{CD}^{+} \mathrm{T}$-lymphocytes in ischemia has been elegantly demonstrated. In a liver ischemia model, $\mathrm{CD} 4^{+} \mathrm{T}$ cell deficient mice had significantly less hepatic damage [236]. This response to ischemic injury is initially independent from allogenicity: Heemann et al have demonstrated that the pattern of cellular infiltration and cytokine expression in both syngeneic and allogeneic cardiac grafts was similar if not identical within the first $48-72 \mathrm{~h}$ after engraftment [84]. Thus, as result of the transplant procedure, a complete network of cytokines is already activated, even before allogeneic reactions develop. Some pretransplant conditions of both donor and recipient, as discussed in the etiology section, appear to aggravate this initial injury.

\section{Alloimmune response}

The recognition of histoincompatible MHC alloantigens will provoke an alloimmune response. Class I antigens, constitutively expressed on nucleated cells, interact with $\mathrm{CD} 8^{+}$cells, and class II antigens, constitutively expressed on lymphoid cells and inducible on endothelial cells, macrophages and fibroblasts are recognised by $\mathrm{CD}^{+}$cells. Intact foreign MHC molecules on donor cells may be directly recognised by $\mathrm{T}$ cells, either in combination with an allopeptide or a selfpeptide, which results in an exceptionally strong immune response. Frequencies of T cell precursors that respond to alloantigens are 10-100 fold higher than for other nominal antigens [182]. In draining lymph nodes and spleen, alloreactive T-cells recognise donor MHC indirectly, presented by self-MHC molecules on recipient antigen presenting cells [190].

In allorecognition, the MHC antigen is bound to the $\mathrm{T}$ cell receptor. For activation of T-cells, costimulatory pathways as the CD28 receptor on T cells with its ligand B7, and CD40 with its T-cell based ligand, CD40L are mandatory for the promotion of T-cell effector function and proliferation. The adhesion molecules ICAM-1, VCAM-1 and LFA-3 have also been shown to co-stimulate $\mathrm{T}$ cell activation. Once the $\mathrm{CD} 4^{+} \mathrm{T}$ cell is activated, a cascade of events amplifies the alloimmune response: Secreted IL-2 leads to clonal proliferation of alloreactive cells and stimulates $\mathrm{CD} 8^{+} \mathrm{T}$ cells to develop into mature cytotoxic effector cells. Release of cytokines such as IFN $\gamma$ and TNF $\alpha$ may further increase the expression of adhesion molecules, and MHC antigens on the endothelium, smooth muscle cells and parenchymal cells. IFN $\gamma$ is also responsible for the activation of macrophages, which together with $\mathrm{CD} 8^{+}$cells are cytotoxic to the graft cells, leading to acute graft failure, when no immunosuppressive intervention is given to prevent or to overcome this $\mathrm{CD} 4^{+} \mathrm{T}$-cell mediated alloimmune response.

Despite inhibition of $\mathrm{T}$ cell activation by cyclosporine, FK 506, or anti-IL2 monoclonal antibodies, these therapies do not prevent the development of CTD in clinical transplantation, probably due to too low doses of these drugs. In experimental models, continuously high doses of cyclosporin A or blockade of CD28/B7 and $\mathrm{CD} 40 / \mathrm{CD} 40 \mathrm{~L}$ costimulatory pathways decrease early infiltration and almost completely inhibit intimal hyperplasia in murine aortic and cardiac allografts $[65$, $171,199,205]$. Evidence that the $\mathrm{CD}^{+} \mathrm{T}$ cell is involved in the genesis of intimal hyperplasia is elegantly exemplified by Shi et al: Carotid allografts in mice that were genetically deficient for the CD4 + T cell developed intimal thickening to only $40 \%$ of that seen in controls [184]. 


\section{Anti-donor specific antibodies}

The cytokines IL-4, IL- 6 , and IL-10 released by activated $\mathrm{CD}^{+}$cells are growth- and differentiation factors for B cells. Activation of B cells may result in maturation into plasma cells with allospecific antibody production. Since immunoglobulin, complement, and antigenantibody complexes have been found in areas of intimal hyperplasia [15, 170, 216], humoral activity has long been thought to be primarily responsible for CTD. A recent finding of upregulated immunoglobulin J chain in arteriosclerotic lesions suggests the presence of IgM- or IgA-producing plasma cells in such grafts [31]. Donorspecific antibodies are found against HLA antigens, endothelial cells, mesangial cells, glomerular and tubular basement membrane, smooth muscle cells and the nucleus $[99,201]$.

The precise significance of antibody deposition that mitigates over time, as shown in many animal models $[64,77,78]$, remains to be established. In experiments with SCID mice, which lack $T$ and $B$ cell mediated cellular responses, passive transfer of anti-donor specific antibody was sufficient to produce graft arteriosclerosis with a perivascular mononuclear cell infiltrate in longstanding cardiac allografts [174]. While some investigators found that the degree of intimal hyperplasia aortic and cardiac allografts in mice recipients with a defect of humoral antibody production was comparable to that seen in immunocompetent mice [34], Russell et al showed that cardiac allografts in B cell deficient mice did not develop fibroproliferative arteritis [173]. These investigators also demonstrated that in two donor-recipient mice combinations in which anti-donor antibodies are generally undetectable, intimal fibrosis was uncommon, whilst these recipients became capable of producing fibrous lesions in allografted hearts when given anti-donor, class I antibody [173]. Similarly to Russell's report, Shi et al showed that $\mathrm{CD}^{+}$cells, humoral antibodies and macrophages together were necessary for intimal hyperplasia in a mouse carotid allograft model. Arteries allografted into mice, deficient in both $\mathrm{T}$ cell receptors and humoral antibody, showed almost no neointimal proliferation, whereas those grafted into mice, deficient only in humoral antibody, developed minimal intimal hyperplasia [184].

The mechanism by which antibodies contribute to CTD is rather speculative. One recent study has shown that anti-HLA antibodies, when attached to their HLA class I antigen on cultured endothelial cells, induce increased gene expression of bFGF receptor and ligand binding, and a 4-6 fold cell proliferation, as it does for smooth muscle cells [80]. Marsh et al hypothetized that IgG induces the accumulation, differentiation and subsequent cytokine production by intimal macrophages via crosslinking of Fc $\gamma \mathrm{R}$ thereby preventing apoptosis of monocytes. Fc $\gamma \mathrm{R}$ crosslinking induces the production of MCP-1 and IL-8, which can promote both macrophage and lymphocyte accumulation $[119,120]$.

\section{Chronic response-to-injury}

It is not clear why this response to the initial injury does not disappear over time, as seen in normal healing processes. In allografts, it is conceivable that the alloantigens are responsible for an ongoing cellular and/or humoral response. $T$ cells decline to relatively low numbers as the process enters its chronic phase, they and their products may continue to provide a persisting low grade immunological response and ongoing subclinical injury to the graft's endothelium and parenchyma over time [221]. Since there is a continuous supply of donor allopeptides processed and presented by host professional APCs (dendritic cells, macrophages, B cells), self-MHC restricted T cells may perpetuate a chronic alloimmune response. Suciu-Foca and collaborators demonstrated a persistent allopeptide reactivity in patients developing CTD $[35,201]$. The continued alloimmune recognition in long term graft recipients is evidenced by the presence of graft reactive cytotoxic $T$ splenocytes in long term recipients of cardiac allografts. Anti-donor specific antibodies may also maintain a chronic alloimmunologic injury: Donor reactive alloantibodies in the recipient's circulation have been demonstrated longterm after engraftment $[149,228]$.

The significance of donor alloantigens on 'non-professional' antigen presenting cells, like the endothelial cells for $T$ cell recognition is unclear. An indication that donor MHC class I and II antigens play a role in the chronic phase has recently been obtained. Carotid allografts from donor mice deficient in MHC II molecules showed a reduction of intimal hyperplasia formation of $33 \%$, primarily due to a reduction in smooth muscle cell accumulation [183]. The absence of such a continuous alloantigeneic stimulus in syngeneic transplants might explain the much more rapid development of CTD in allografts.

Thus, the strength of the initial trigger, the length of the trigger, and the presence of additional factors, and under which alloantigens, determine the onset and the pace of progress of irreversible chronic lesions

\section{Macrophages}

Activated T cells produce, amongst others, the cytokine RANTES (Regulated upon activation, normal T cell expressed and secreted), a macrophage chemoattractant [137]. Other cytokines, such as IL-8, MCP-1 and osteopontin released by interstitial cells and smooth muscle cells are chemotactic for macrophages as well. Upregulated adhesion molecules contribute to their localisation 
in areas of injury. Macrophages invade the graft and become activated by IFN- $\gamma$. The continuous presence, the activated state, and the upregulation of macrophage associated cytokines in long-term allografts with CTD and, in other chronic diseases, with fibrotic features, suggest a pivotal role for the macrophages $[12,172,198]$.

The importance of macrophages was demonstrated by the prevention of CTD by treatment with gammalactone, a synthetic inhibitor of macrophage activity, in a rat renal allograft model [12], and by the observation that carotid allografts in mice deficient in macrophages, developed only slight intimal hyperplasia [184]. Activated macrophages produce a number of cytokines including TNF- $\alpha$, IL- $1 \beta$, PDGF, bFGF, and TGF- $\beta$. This perpetuates and amplifies the fibrogenic signals.

\section{Cytokines and growth factors}

Cytokines and growth factors play an important role in the chronic phase. They have profound effects on cells of the graft and on the immune system. Cytokines and growth factors are pleiotropic, with biological effects on many cell subpopulations, are, furthermore, regulated via autocrine, paracrine or systemic pathways, and there is a great deal of redundancy in the cytokine networks. The advent of the transgenic and knock-out technology has allowed dissecting of the molecular pathways causally involved in allograft arteriosclerosis [200]. No cytokine has been unequivocally identified as specific to alloimmune response.

The redundancy of the cytokine system has been stressed by gene knockout technology: IL-4 is not necessary for the development of graft coronary arteriosclerosis, nor does its absence appear to augment the development of vascular lesions. In addition, TNF $\alpha$-R1 deficiency in either donor heart or recipient does not abrogate the development of graft arteriosclerosis [140]. The increased expression of TGF- $\beta_{1}$ has been linked to transplant arteriosclerosis both by clinical and experimental studies, and transfection of TGF- $\beta$ to the kidney led to increased accumulation of the extracellular matrix and glomerulosclerosis [95]. Interestingly, cardiac allografts in $\mathrm{TGF} \beta_{1}$ deficient recipients developed significantly more intimal hyperplasia than controls [102].

In 1989, IFN- $\gamma$ has already been postulated by Libby et al to play a central role in CTD because of its effects on $T$ cells and macrophages, as outlined above [113]. The availabilty of IFN- $\gamma$ deficient mice permitted this group to test critically the contribution of IFN- $\gamma$ to the development of CTD $[138,139]$. Cardiac allografts in IFN- $\gamma$ deficient mice developed only minimal or no transplant arteriosclerosis as compared to controls. In addition, similar results on graft arteriosclerosis were found after the administration of IFN- $\gamma$ neutralizing antibody in normal rats.

\section{Chronic remodelling}

The process eventually becomes irreversible, but the period in which this occurs is variable: Retransplantation of allogeneic kidney grafts back into the original donor strain prevents CTD, when the retransplant is performed within 12 weeks, but not after this period [219]. In aorta- and cardiac allografts Mennander et al and Izutani et al reported a much shorter time interval after which intimal hyperplasia continues, when the graft was transplanted back into the donor strain $[97,132]$.

\section{Smooth muscle cells}

Once the endothelial cells are injured, the secreted cytokines, i.e. IL-1, PDGF, IGF-1, TGF- $\beta$ and bFGF, and metabolic products such as prostaglandin, nitric oxide, and oxidized low-density lipoproteins induce smooth muscle cell (SMC) proliferation, as reviewed by Ross [169]. Activated T cells and macrophages, often in close anatomical association with the replicating SMC, produce also a whole wealth of these factors. Platelets deposited along the injured vascular wall contribute by secreting PDGF, EGF, TGF- $\beta$ and tromboxane- $\mathrm{A}_{2}$. When SMC migrate to the intima, they transform their phenotype from 'contractile' to 'secretory' and the cells become capable of replication $[169,215]$. In addition, SMC can produce many of these growth factors and may generate similar autocrine or paracrine loops of stimulation for cell replication, as seen in 'classical' atherosclerosis [169]. These factors also may modulate extracellular matrix synthesis, angiogenesis, and leucocyt adhesion. Moreover, activated SMC can express MHC class I and II and may act as antigen presenting cells. Numerous drugs inhibit SMC proliferation, and some, such as angiopeptin, have been shown to be of benefit in organ allografts $[55,130,131]$.

\section{Extracellular matrix}

As the endothelium is damaged, the underlying extracellular matrix can become activated and act as costimulator for leucocytes to facilitate recruitment and extravasation. For instance, exposed collagens and fibronectin may act as costimulators for activated $\mathrm{CD} 4^{+}$ T-cells $[43,126]$. After activation by antigens, $T$ cells synthesize heparanase, which facilitates migration through tissue [61]. The cleavage of heparan sulphate by this enzyme also activates and releases fibrogenic growth factors, such as basic fibroblast growth factor in the extracellular matrix [66]. TGF- $\beta$, produced by the activated T cells and macrophages, stimulates the production of ECM molecules and inhibits the matrix degrading enzymes. The thickening of basal membranes, 
such as that of the pericapillary and glomerular endothelium in the transplanted kidney, interstitial fibrosis and sclerosis, and in intima hyperplasia smooth muscle cell proliferation is accompanied by excessive synthesis of connective tissue proteins.

\section{Conclusion}

CTD is currently the main cause of late graft failure. It is usually associated with previous acute rejection epi- sodes, although several non-alloantigen-associated factors, like ischemia, hyperlipedimia, and hypertension may enhance the process. We propose that the process leading to CTD in allografts begins at the time of graft retrieval, is enhanced by ischemic injury, which provokes an alloimmune response to the endothelial cells, the extracellular matrix and parenchyma. An ongoing alloimmune response, in which several non-alloimmune factors may interfere, eventually leads to irreversible lesions of the graft.

\section{References}

1. Abbasoglu O, Levy MF, Brkic BB, Testa G, Jeyarajah DR, Goldstein RM, Husberg BS, Gonwa TA, Klintmalm GB (1997) Ten years of liver transplantation: an evolving understanding of late graft loss. Transplantation 64: 1801-1807

2. Abu-Elmagd KM, Tzakis A, Todo S, Reyes J, Fung J, Nakamura K, Wright H, Furukawa H, Demetris J, Van Thiel DH, Starzl TE (1993) Monitoring and treatment of intestinal allograft rejection in humans. Transplant Proc 25: 1202-1203

3. Adams DH, Karnovsky MJ (1989) Hypercholesterolemia does not exacerbate arterial intimal thickening in chronically rejecting rat cardiac allografts. Transplant Proc 21: 437-439

4. Adams DH, Russell ME, Hancock WW, Sayegh MH, Wyner LR, Karnovsky MJ (1993) Chronic rejection in experimental cardiac transplantation: studies in the Lewis-F344 model. Immunol Rev 134: 5-19

5. al-Bader W el-R, Landsberg D, Manson AD, Levin A (1996) Renal function changes over time in adult recipients of small pediatric kidneys. Evidence against hyperperfusion injury. Transplantation 62: 611-615

6. Almond PS, Matas AJ, Gillingham KJ Dunn DL, Payne WD, Gores P, Gruessner R, Najarian JS (1993) Risk factors for chronic rejection in renal allograft recipients. Transplantation 55: 752-757

7. Alonso DR, Storek PK, Minick R (1977) Studies on the pathogenesis of atherosclerosis induced in rabbit cardiac allografts by the synergy of graft rejection and hypercholesterolemia. Am J Pathol 87: 415-442
8. Andersen HØ, Holm P, Stender S, Hansen BF, Kjeldsen K, Nordestgaard $\mathrm{BG}$ (1995) Relative importance of ischemic injury and immunological injury on the development of transplant arteriosclerosis in rabbit aortic allografts. Transplantation 60: 631-638

9. Annual Report 1998 of Eurotransplant Foundation: preliminary data

10. Annual report: UNOS 1996, Annual Report of the U.S. Scientific Registry of Transplant Recipients and the Organ Procurement and Transplantation Network

11. Azuma H, Nadeau K, Takada M, Mackenzie HS, Tilney NL (1997) Cellular and molecular predictors of chronic renal dysfunction after initial ischemia/reperfusion injury of a single kidney. Transplantation 64: 190-197

12. Azuma H, Nadeau KC, Ishibashi M, Tilney NL (1995) Prevention of functional, structural, and molecular changes of chronic rejection of rat renal allografts by a specific macrophage inhibitor. Transplantation 60: 1577-1582

13. Baan CC, Holweg CTJ, Niesters HGM, Van Gelder T, Mol WM, Mochtar B, Balk AHMM, Weimar W (1997) Intragraft cytokine and growth factor mRNA expression in relation to graft vascular disease after heart transplantation. Transplant Proc 29: 2529-2530

14. Backman L, Gibbs J, Levy M, McMillan R, Holman M, Husberg B, Goldstein R, Gonwa TA, Klintmalm G (1993) Causes of late graft loss after liver transplantation. Transplantation 55: 1078-1082

15. Baldwin WM III, Hutchinson IF, Meijer CJ, Tilney NL (1981) Immune responses to allografts. Marked decrease in medullary thymocytes and splenic $\mathrm{T}$ lymphocytes after cyclosporin A treatment. Transplantation 31: 117-120
16. Baldwin WM, Pruitt SK, Brauer RB, Daha MR, Sanfilippo F (1995) Complement in organ transplantation. Transplantation 59: 797-808

17. Bando K, Paradis IL, Similo S, Konishi H, Komatsu K, Zullo TG, Yousem SA, Close JM, Zeevi A, Duquesnoy RJ, et al (1995) Obliterative bronchiolitis after lung and heart-lung transplantation. An analysis of risk factors and management. J Thorac Cardiovasc Surg 110: 4-13

18. Barbir M, Kushwha S, Hunt B, Macken A, Thompson GR, Mitchell A, Robinson D, Yacoub M (1992) Lipoprotein (a) and accelerated coronary artery disease in cardiac allograft recipients. Lancet 340: 1500-1502

19. Basadonna GP, Matas AJ, Gillingham KJ, Payne WD, Dunn DL, Sutherland DE, Gores PF, Gruessner RW, Najarian JS (1993) Early versus late acute renal allograft rejection: impact on chronic rejection. Transplantation 55: 993-995

20. Beckingham IJ, Dennis MJS, Bishop MC, Blamey MC, Smith SJ, Nicholson ML (1994) Effect of human leucocyte antigen matching on the incidence of acute rejection in renal transplantation. Br J Surg 81: 574-577

21. Beetsch JW, Park TS, Dugan LL, Shah AR, Gidday JM (1998) Xanthine oxidase-derived superoxide causes reoxygenation injury of ischemic cerebral endothelial cells. Brain Res 786: 89-95

22. Benediktsson H, Chea R, Davidoff A, Paul LC (1996) Antihypertensive drug treatment in chronic renal allograft rejection in the rat. Effect on structure and function. Transplantation 62: 1634-1642

23. Bieber CP, Hunt SA, Schwinn DA, Jamieson SA, Reitz BA, Oyer PE, Shumway NE, Stinson BE (1981) Complications in long term survivors of cardiac transplantation. Transplant Proc 13: 207-211 
24. Bittar AE, Keitel E, Garcia CD, Bruno RM, Silviera AE, Messias A, Garcia VD (1992) Patient non-compliance as a cause of late kidney graft failure. Transplant Proc 24: 2720-2721

25. Brenner BM, Cohen RA, Milford EL (1992) In renal transplantation, one size may not fit all. JASN 3: 162-169

26. Briscoe DM, Cotran RS, Pober JS (1992) Effects of tumor necrosis factor, lipopolysaccharide, and IL-4 on the expression of vascular endothelial cell adhesion molecule-1 in vivo: Correlation with CD3 $+\mathrm{T}$ cell infiltration. J Immunol 149: 2954-2960

27. Briscoe DM, Schoen FJ, Rice GE, Bevilacqua MP, Ganz P, Prober JS (1991) Induced expression of endothelial-leucocyte adhesion molecules in human cardiac allografts. Transplantation 51: 537-539

28. Brunner-La Rocca HP, Schneider J, Kunzli A, Turina M, Kiowski W (1998) Cardiac allograft rejection late after transplantation is a risk factor for graft coronary artery disease. Transplantation 65: 538-43

29. Buerke M, Prufer D, Dahm M, Oelert H, Meyer J, Darius H (1998) Blocking of classical complement pathway inhibits endothelial adhesion molecule expression and preserves ischemic myocardium from reperfusion injury. J Pharmacol Exp Ther 286: 429-438

30. Cheigh JS, Haschemeyer RH, Wang JC, Riggio RR, Tapia L, Stenzl KH, Rubin AL (1989) Hypertension in kidney transplant recipients. Effect on long-term renal allograft survival. Am J Hypertens 2: 341-348

31. Chen J, Myllärniemi M, Akyürek LM, Häyry P, Marsden PA, Paul LC (1996) Identification of differently expressed genes in rat aortic allograft vasculopathy. Am J Pathol 149: 597-611

32. Cheng LP, Kuwahara M, Jacobsson J, Foegh ML (1991) Inhibition of myointimal hyperplasia and macrophage infiltration by oestradiol in aorta allografts. Transplantation 52: 967-972

33. Chertow GM, Milford EL, Mackenzie HS, Brenner BM (1996) Antigen-independent determinants of cadaveric kidney transplant failure. JAMA 276: 1732-1736

34. Chow LH, Huh S, Jiang J, Zhong R, Pickering JG (1996) Intimal thickening develops without humoral immunity in a mouse aortic allograft model of chronic vascular rejection. Circulation 94: 3079-3082
35. Ciubotariu R, Liu Z, Colovai AI, Ho E, Itescu S, Ravalli S, Hardy MA, Cortesini R, Rose EA, Suciu-Foca N (1998) Persistent allopeptide reactivity and epitope spreading in chronic rejection of organ allografts. J Clin Invest 101: 398-405

36. Colson YL, Zadach K, Nalesnik M, Ildstad ST (1995) Mixed allogeneic chimerism in the rat-donor-specific transplantation tolerance without chronic rejection for primarily vascularized cardiac allografts. Transplantation 60: 971-980

37. Colvin RB (1990) Cellular and molecular mechanisms of allograft rejection. Ann Rev Med 41: 361-375

38. Connolly J, Dyer P, Martin S, Parrott N, Pearson R, Johnson R (1996) Importance of minimizing HLA-DR mismatch and cold preservation time in cadaveric renal transplantation. Transplantation 61: 709-714

39. Cosio FG, Pelletier RP, Falkenhain ME, Henry ML, Elkhammas EA, Davies EA, Bumgardner GL, Ferguson RM (1997) Impact of acute rejection and early allograft function on renal allograft survival.Transplantation 63: 1611-1615

40. Costanzo MR, Naftel DC, Pritzker MR, Heilman JK 3rd, Boehmer JP, Brozena SC,Dec GW, Ventura HO, Kirklin JK, Bourge RC, Miller LW (1998) Heart transplant coronary artery disease detected by coronary angiography: a multiinstitutional study of preoperative donor and recipient risk factors. Cardiac Transplant Research Database. J Heart Lung Transplant 17: 744-753

41. Cramer DV, Chapman FA, Wu GD, Harnaha JB, Qian SQ, Makowka L (1990) Cardiac transplantation in the rat. II. Alteration of the severity of donor graft arteriosclerosis by modulation of the host response. Transplantation 50: 554-558

42. Dammin GJ (1966) Renal transplant: correlations of histological patterns with function in the kidney. In: Mostofi FK, Smith DE (eds) The Kidney. Williams and Wilkins, pp 445-468

43. Dang NH, Torimoto $Y$, Schlossman S, Morimoto C (1990) Human CD4 helper T cell activation: functional involvement of two distinct collagen receptors, IF7 and VLA integrin family. J Exp Med 172: 649-652

44. Danoff TM, Hallows KR, Burns JE, Brayman KL, Feldman HI (1999) Renal allograft survival in AfricanAmericans: Influence of the Duffy blood group. Transplantation 67:\$8
45. Davenport A, Younie ME, Parsons JEM, Klouda PT (1994) Development of cytotoxic antibodies following renal allograft transplantation is associated with reduced graft survival due to chronic vascular rejection. Nephrol Dial Transplant 9: 1315-1319

46. Deligeorgi-Politi H, Wight DG, Calne RY (1994) Chronic rejection of liver transplants revisited. Transpl Int 7: 442-447

47. Diamond JR, Tilney NL, Frye J, Ding G, McElroy J, Pesek-Diamond I, Yang H (1992) Progressive albuminuria and glomerulosclerosis in a rat model of chornic renal allograft rejection. Transplantation 54: 710-716

48. Dimeny E, Fellstrom B, Larsson E, Tufveson G, Lithell H (1993) Hyperlipoproteinemia in renal transplant recipients: is there a linkage with chronic rejection? Transplant Proc 25: 2065-2066

49. Dubel L, Farges O, Johanet C, Sebagh M, Bismuth $\mathrm{H}$ (1998) High incidence of anti-tissue antibodies in patients experiencing chronic liver allograft rejection. Transplantation 65: 1072-1075

50. Duijvestein AM, Van Breda Vriesman PJC (1991) Chronic renal allograft rejection. Selective involvement of the glomerular endothelium in humoral immune reactivity and intravascular coagulation. Transplantation 52: 195-202

51. Dunn J, Golden D, Van Buren CT, Lewis RM, Lawen J, Kahan BD (1990) Causes of graft loss beyond two years in the cyclosporine era. Transplantation 49: 349-353

52. Escobar A, Ventura HO, Stapleton DD, Mehra MR, Ramee SR, Collins TJ, Jain SP, Smart FW, White CJ (1994) Cardiac allograft vasculopathy assessed by intravascular ultrasonography and nonimmunologic risk factors. Am J Cardiol 74: 1042-1046

53. Fangman J, Frühauf N, Oldhafer K, Offner G (1999) Living related and cadaveric kidney transplantationWhat are the major differences? Transpl Proc 31: 203-204

54. Fellström B, Akyürek ML, Dimény E, Kaijser M, Larsson E, Wanders A, Wahlberg J (1996) Nonimmunological factors involved in long-term renal allograft deterioration. Adv Nephrol Necker Hosp 25: 51-62

55. Fellström B, Dimeny E, Foegh ML, Larsson E, Wanders A, Tufveson G (1991) Accelerated atherosclerosis in heart transplants in the rat simulating chronic vascular rejection: effects of prostacyclin and angiopeptin. Transplant Proc 23: 525-528 
56. Fellstrom B, Dimeny E, Larsson E, Claesson K, Tufveson G (1990) Rapidly proliferating arteriopathy in cyclosporin-induced permanently surviving rat cardiac allografts simulating chronic vascular rejection. Clin Exp Immunol 80: 288-292

57. Ferguson R (1994) Acute rejection episodes - Best predictor of long-term primary cadaveric renal transplant survival. Clin Transplanation 8: 328-331

58. Ferry BL, Welsh KI, Dunn MJ, Law D, Proctor J, Chapel H, Yacoub MH, Rose ML (1997) Anti-cell surface endothelial antibodies in sera from cardiac and kidney transplant recipients: association with chronic rejection. Transpl Immunol 5: 17-24

59. Foegh M, Rego A, Lou H, Katz N, Ramwell P (1995) Gender effects on myointimal hyperplasia. Transpl Proc 27: 2070-2072

60. Freese DK, Snover DC, Sharp HL, Gross CR, Savick SK, Payne WD (1991) Chronic rejection after liver transplantation: a study of clinical, histopathological and immunological features. Hepatology 13: 882-891

61. Fridman R, Lider O, Napaestek, Fuks Z, Vlodavsky I, Cohen IR (1987) Soluble antigen induces $T$ lymphocytes to secrete an endoglycosidase that degrades the heparan sulphate moiety of subendothelial extracellular matrix. J Cell Physiol 130: 85-92

62. Fuggle S, Sanderson JB, Gray DWR, Richardson A, Morris PJ (1993) Variation in expression of endothelial adhesion molecules in pretransplant and transplanted kidneys - correlation with intragraft events. Transplantation 55: $117-123$

63. Gao SZ, Schroeder JS, Alderman EL, Hunt SA, Silverman JF, Wiederhold V, Stinson EB (1987) Clinical and laboratory correlates of accelerated coronary disease in the cardiac transplant patient. Circulation 76:V56-61

64. Geerling RA, Ansari AA, LafondWalker AM, Baumgartner WA, Herskowitz A (1998) Accelerated arteriosclerosis in aortic grafts: a role for activated complement and IgM antibody in early lesion development. Trans plant Proc 30: 1017-1019

65. Geerling RA, De Bruin RWF, Scheringa $\mathrm{M}$, Bonthuis $\mathrm{F}$, Jeekel J, IJzermans JNM, Marquet RL (1994) Suppression of acute rejection prevents graft arteriosclerosis after allogeneic aorta transplantation in the rat. Transplantation 58: 1258-1263
66. Gilat D, Cahalon L, Hershkoviz R, Lider O (1996) Interplay of T cells and cytokines in the context of enzymatically modified extracellular matrix. Immunology Today 17: 16-20

67. Gjertson DW (1996) A multi-factor analysis of kidney graft outcomes at one and five years posttransplantation: 1996 UNOS update. In: Cecka JM, Terasaki PI (eds) Clinical Transplants. UCLA Tissue Typing Laboratory, Los Angeles, California, pp 343-360

68. Gjertson DW (1991) Survival trends in long-term first cadaver-donor kidney transplants. In: Terasaki P (ed) Clinical Transplant. UCLA Tissue Typing Laboratory, Los Angeles, CA, pp 225-235

69. Glassock RJ, Feldman D, Reynolds ES, Dammin GJ, Merrill JP (1968) Human renal isografts: a clinical and pathologic analysis. Medicine 47: 411-454

70. Grant D (1996) Current results of intestinal transplantation. Lancet 347: 1801-1803

71. Gratton MT, Moreno-Cabral CE, Starnes VA, Oyer PE, Stinson EB, Shumway NE (1989) Cytomegalovirus infection is associated with cardiac allograft rejection and atherosclerosis. JAMA 261: 3561-3566

72. Grinyo JM, Gil-Vernet S, Moreso F, Serón D, Fulladosa X, Cruzado JM, Riera L, Anunciada AI, Hueso M, Alsina J (1997) Ischemia-reperfusion injury as a risk factor for late kidney graft failure. In: Touraine JL, Traeger J, Bétuel H, Dubernaed JM, Revillard JP, Dupuy C (eds) Late graft loss. Kluwer Academic, London, pp 77-83

73. Halloran PF, Aprile M, Farewell V (1998) Early function as the principal correlate of graft survival. Transplantation 46: 223-228

74. Halloran PF, Cockfield SM, Madrenas AJ (1989) The mediators of inflammation (interleukin-1, Interferon- $\gamma$, and Tumor necrosis factor) and their relevance to rejection. Transplant Proc 21: $26-30$

75. Halloran PF, Schlaut J, Solez K, Srinivasa NS (1992) The significance of anti class I response. Clinical and pathological features of renal transplants with anti class I antibody. Transplantation 53: 550-555

76. Halloran PF, Wadgymar A, Autenried $P$ (1986) The regulation of expression of major histocompatibility complex products. Transplantation 41: 413-420
77. Hancock WH, Whitley WD, Tullius SG, Heemann UW, Wasowska B, Baldwin WM III, Tilney NL (1993) Cytokines, adhesion molecules, and the pathogenesis of chronic rejection of rat renal allografts. Transplantation 56: $643-650$

78. Hancock WW, Shi C, Picard MH, Bianchi C, Russell ME (1995) LEW-toF344 carotid artery allografts: analysis of a rat model of posttransplant vascular injury involving cell-mediated and humoral responses. Transplantation 60: $1565-1572$

79. Hariharan S, Mcbride MA, Bennett LE, Cohen EP (1997) Risk factors for renal allograft survival from older cadaver donors. Transplantation 64 : 1748-1754

80. Harris PE, Bian H, Reed EF (1997) Induction of high affinity fibroblast growth factor receptor expression and proliferation in human endothelial cells by anti-HLA antibodies: a possible mechanism for transplant atherosclerosis. J Immunol 159: 5697-5704

81. Hayry P, Mennander A, Yilmaz S, Ustinov J, Raisanen A,Miettinen A, Lautenschlager I, Lemstrom $\mathbf{K}$, Bruggeman CA, Paavonen T (1992) Towards understanding the pathophysiology of chronic rejection. Clin Invest 70: 780-790

82. Hayry P, Yilmaz S, Lemstrom K, Koskinen $P$, Raisanen-Sokolowski A Mennander A, Krogerus L, Taskinen E, Paavonen T, Myllarniemi M, Kallio $\mathrm{E}$, Aaavik E, Alatalo S, Isoniemi $\mathrm{H}$ (1996) Molecular biology of chronic rejection and predictive value of biopsies. In: Solez K, Racusen LC, Billingham ME (eds) Solid organ transplant rejection. Marcel Dekker, New York, pp 77-105

83. Heemann UW, Azuma H, Tullius SG, Mackenzie H, Brenner BM, Tilney NI (1994) The contribution of reduced functioning mass to chronic kidney allograft dysfunction in rats. Transplantation 58: 1317-1322

84. Heemann UW, Tullius SG, Azuma H, Tilney NL (1996) Early patterns of cellular infiltration and cytokine and extracellular matrix protein expression reflect reperfusion injury after cardiac transplantation in rats. In: Faist E (ed) The immune consequences of trauma, shock and sepsis. Pabst Science Publishers, Lengerich, pp 628-634 
85. Heer de E, Davidoff A, van der Wal A, van Geest M, Paul LC (1994) Chronic renal allograft rejection in the rat. Transplantation-induced antibodies against basement membrane antigens. Lab Invest 70: 494-502

86. Hirt SW, You XM, Möller F, Boeke K, Ernst M, Starke M, Spranger U, Wottge HU (1999) Early treatment of acute rejection prevents chronic rejection in a rat model of allogenic left lung transplantation. Transpl Proc 31: 1005-1006

87. Van der Hoeven JAB, Ploeg RJ, Postema F, Molema G, de Vos P, Girbes ARJ, Van Suylichem PTR, ter Horst GJ (1999) Induction of organ dysfunction and activation of inflammatory markers in donor liver and kidney during hypotensive brain death. Transplant Proc 31: 1006-1007

88. Hornick P, Smith J, Pomerance A, Mitchell A, Banner N, Rose M, Yacoub M (1997) Influence of acute rejection episodes, HLA matching, and donor/recipient phenotype on the development of 'early' transplant-associated coronary artery disease.Circulation 96: 148-153

89. Hosenpud JD, Edwards EB, Lin HM, Daily OP (1996) Influence of HLA matching on thoracic transplant outcomes. An analysis from the UNOS/ ISHLT Thoracic Registry. Circulation 94: 170-174

90. Hosenpud JD, Mauck KA, Hogan KB (1997) Cardiac allograft vasculopathy: IgM antibody responses to donor-specific vascular endothelium. Transplantation 63: 1602-1606

91. Hruban RH, Beschorner WE, Baumgartner WA,Augustine SM, Ren $\mathrm{H}$, Reitz BA, Hutchins GM (1990) Accelerated arteriosclerosis in hear transplant recipients is associated with a T-lymphocyte-mediated endothelialitis. Am J Pathol 137: 871-882

92. Humar A, Kerr S, Hassoun A, Granger D, Suhr B, Matas A (1993) The association between acute rejection and chronic rejection in kidney transplantation. Transpl Proc 31: 1302-1303

93. Ibrahim S, Jacobs F, Zukin Y, Enriquez D, Holt D, Baldwin W $3^{\text {rd }}$, Sanfilippo F, Ratner LE (1996) Immunohistochemical manifestations of unilateral kidney ischemia. Clin Transplant 10: 646-652

94. Inauen W, Payne DK, Kvietys PR, Granger DN (1990) Hypoxia/reoxygenation increases the permeability of endothelial cell monolayers: role of oxygen radicals. Free Radic Biol Med 9: 219-223
95. Isaka Y, Fujuwara Y, Ueda N, Kaneda Y, Kamada T, Imai E (1993) Glomerulosclerosis induced by in vivo transfection of transforming growth factor $\beta$ or platelet derived growth factor gene into the rat kidney. J Clin Invest 92: 2597-2601

96. Isoniemi HM, Krogerus L, Von Willebrand E, Taskinen E, Ahonen J, Häyry P (1992) Histopathological findings in well-functioning, long-term renal allografts. Kidney Int 41: 155-160

97. Izutani $\mathbf{H}$, Miyagawa $S$, Shirakura $R$, Matsumiya G, Nakata S, Shimazaki Y, Matsuda H (1995) Evidence that graft coronary arteriosclerosis begins in the early phase after transplantation and progresses without chronic immunoreaction. Histopathological analysis using a retransplantation model. Transplantation 60: 1073-1079

98. Jain A, Fung JJ, Reyes J, Kashyap R, Rohal S, Rakela J, Starzl TE (1998)

Primary liver transplantation in infants, children, adults, and seniors: 1000 consecutive patients from single centre with 5 to 8 years actual follow-up. Abstract book, XVII World Congress Transplantation Society, Montreal

99. Jeannet M, Pinn VW, Flax MH, Russell PS (1970) Humoral antibodies in renal allotransplantation in man. N Engl J Med 282: 111-117

100. Katznelson S, Gjertson DW, Cecka JM (1995) The effect of race and ethnicity on kidney allograft outcome. In: Terasaki PI (ed) Clinical Transplant 1995. UCLA Tissue Typing Laboratory, Los Angeles, CA, pp 379-394

101. Knight RJ, Dikman S, Liu H, Martinelli GP (1997) Cold ischemic injury accelerates the progression to chronic rejection in a rat cardiac allograft. Transplantation 64: 1102-1107

102. Koglin J, Glysing-Jensen T, RaisanenSokolowski A, Russell ME (1998) Immune sources of transforming growth factor-beta1 reduce transplant arteriosclerosis: insight derived from a knockout mouse model. Circ Res 83: $652-660$

103. Koskinen P, Lemström K, Häyry P (1995) How cyclosporine modifies histological and molecular events in the vascular wall during chronic rejection of rat cardiac allografts. Am J Path 146: 972-978

104. Kouwenhoven EA, de Bruin RWF, Heemann UW, Marquet RL, IJzermans JNM (1999) Late graft dysfunction after prolonged cold ischemia of the donor kidney. Inhibition by cyclosporine. Transplantation 68: 1004-1010
105. Kroshus TJ, Kshettry VR, Savik K, John R, Hertz MI, Bolman RM $3^{\text {rd }}$ (1997) Risk factors for the development of bronchiolitis obliterans syndrome after lung transplantation. J Thorac Cardiovasc Surg 114: 195-202

106. Kusaka M, Ziai F, Hancock WH, Tilney NL, Mackenzie HS (1999) Systemic hypertension accelerates chronic rejection of renal allografts in the rat. Transplant Proc 31: 869

107. Land W, Schneeberger H, Schleibner S, Illner WD, Abendroth D, Rutili G, Arfors KE, Messmer K (1994) The beneficial effect of human recombinant superoxide dismutase on acute and chronic rejection events in recipients of cadaveric renal transplants. Transplantation 57: 211-217

108. Lautenschlager I, Hockerstedt K, Jalanko H, Loginov R, Salmela K, Taskinen E, Ahonen J (1997) Persistent cytomegalovirus in liver allografts with chronic rejection. Hepatology 25: 190-194

109. Lautenschlager I, Soots A, Krogerus L, Kauppinen H, Saarinen O, Bruggeman C, Ahonen J (1997) Effect of cytomegalovirus on an experimental model of chronic renal allograft rejection under triple-drug treatment in the rat. Transplantation 64: 391-398

110. Lemstrom K, Bruning J, Bruggeman C, Lautenschlager I, Hayry P (1993) Cytomegalovirus infection enhances smooth muscle cell proliferation and intimal thickening of rat aortic allografts. J Clin Invest 92: 549-558

111. Lemstrom K, Koskinen P, Krogerus L, Daemen M, Bruggeman C, Hayry $P$ (1995) Cytomegalovirus antigen expression, endothelial cell proliferation, and intimal thickening in rat cardiac allografts after cytomegalovirus infection. Circulation 92: 2594-2604

112. Ley K, Tedder TF (1995) Leucocyte interactions with vascular endothelium-New insights into selectin-mediated attachment and rolling. J Immunol 155: 525-528

113. Libby P, Salamon RN, Payne DD, Schoen FJ, Pober JS (1989) Functions of vascular wall cells related to development of transplantation-associated coronary arteriosclerosis. Transpl Proc 21: 3677-3684

114. Libby P, Takana H (1994) The pathogenesis of coronary arteriosclerosis (chronic rejection) in transplanted hearts. Clin Transplantation 8: 313-318 
115. Lindholm A, Ohlman S, Albrechtsen D, Tufveson G, Persson H, Persson NH (1993) The impact of acute rejection episodes on long-term graft function and outcome in 1347 primary cadaveric renal transplants treated by 3 cyclosporine regimens. Transplantation 7: 343-352

116. Lou H, Kodama T, Zhao J, Maurice P, Wang YN, Katz N, Foegh ML (1996) Inhibition of transplant coronary arteriosclerosis in rabbits by chronic oestradiol treatment is associated with $a b$ olition of MHC class II antigen expression. Circulation 94: 3355-3361

117. Mackenzie HS, Azuma H, Rennke HG, Tilney NL, Brenner BM (1995) Renal mass as a determinant of late allograft outcome: insights from experimental studies in rats. Kidney Int 52: $38-42$

118. Marlin SD, Springer TA (1987) Purified intercellular adhesion moleclule-1 (ICAM-1) is a ligand for lymphocyte function-associated antigen-1 (LFA1). Cell 51: 813-819

119. Marsh CB, Gadek JE, Kindt GC, Moore SA, Wewers MD (1995) Monocyte Fc gamma receptor crosslinking induces IL-8 production. J Immunol 155: 3161-3167

120. Marsh CB, Wewers MD, Tan LC, Rovin $\mathrm{BH}$ (1997) Fc gamma receptor crosslinking induces peripheral blood mononuclear cell MCP-1 expression. J Immunol 158: 1078-1084

121. Martin S, Dyer PA, Mallick NP, Gokal R, Harris R, Johnson RWG (1987) Post-transplant antidonor lymphocytotoxic antibody production in relation to graft outcome. Transplantation 44: 50-53

122. Massy ZA, Guijarro C, Wiederkehr MR, Ma JZ, Kasiske BL (1996) Chronic renal allograft rejection: immunologic and non-immunologic risk factors. Kidney Int 49: 518-524

123. Matas A, Gillingham K, Sutherland DE (1993) Half-life and risk factors for kidney transplant outcome- importance of death with function. Transplantation 55: 757-761

124. Matas A (1994) Chronic rejection in renal transplants - Risk factors and correlates. Clin Transplantation 8: 332-335

125. Matas AJ, Gillingham KJ, Payne WD, Najarian JS (1994) The impact of an acute rejection epsiode on long-term renal allograft survival $(\mathrm{t} 1 / 2)$. Transplantation 57: 857-859
126. Matsuyama T, Yamada A, Kay J, Yamada KM, Akiyama SK, Schlossman SF, Morimoto C (1989) Activation of CD4 cells by fibronectin and anti-CD3 antibody. A synergistic effect mediated by VLA- 5 fibronectin receptor complex. J Exp Med 170: 1133-38

127. Mayadas TN, Johnson RC, Rayburn H, Hynes RO, Wagner DD (1993) Leucocyte rolling and extravasation are severely compromised in P-selectin-deficient mice. Cell 74: 541-554

128. McDonald K, Rector TS, Braunlin EA, Kubo SH, Olivari MT (1989) Association of coronary artery disease in cardiac transplant recipients with cytomegalovirus infection. Am $\mathbf{J}$ Pathol 64: 359-362

129. McGiffin DC, Savunen T, Kirklin JK, Naftel DC, Bourge RC, Paine TD, White-Williams C, Sisto T, Early L (1995) Cardiac transplant coronary artery disease. A multivariable analysis of pretransplantation risk factors for disease development and morbid events. J Thorac Cardiovasc Surg 109: 1081-1088

130. Meiser BM, Wolf S, Devens CH, Wenke K, Thiery J, Kreuzer E, Hammer C, Billingham ME, Reichart B (1992) Continuous infusion of angiopeptin significantly reduces accelerated graft vessel disease induced by FK506 in a rat heart allograft model. Transpl Proc 24: 1671-1672

131. Mennander A, Raisanen A, Paavonen T, Hayry P (1993) Chronic rejection in the rat aortic allograft.V. Mechanism of the angiopeptin (BIM 23014C) effect on the generation of allograft arteriosclerosis. Transplantation 55: 124-28

132. Mennander A, Hayry P (1996) Reversibility of allograft arteriosclerosis after retransplantation to donor strain. Transplantation 62: 526-529

133. Mennander AA, Tikkanen MJ, Raisanen-Sokolowski AK, Ustinov J, Hayry P (1993) Chronic rejection in rat allografts. IV. Effect of hypercholesterolemia in allograft arteriosclerosis. J Heart Lung Transplant $12: 123-132$

134. Michel J-B, Plissonier D, Bruneval P (1992) Effect of perindopril on the immune arterial wall remodeling in the rat model of arterial graft rejection. Am J Med 92:S39-46

135. Miles AM, Sumrani N, John S, Markell MS, Distant DA, Maursky V, Hong JH, Friedman EA, Sommer B (1996) The effect of kidney size on cadaveric renal allograft outcome. Transplantation 61: 894-897
136. Monga G, Mazzucco G, Novara R, Reale L (1990) Intertubular capillary changes in kidney allografts: an ultrastructural study in patients with transplant glomerulopathy. Ultrastruct $\mathrm{Pa}$ thol 14: 201-209

137. Nadeau KC, Azuma H, Tilney NL (1995) Sequential cytokine dynamics in chronic rejection of rat renal allografts: roles for cytokines RANTES and MCP-1. Proc Natl Acad Sci USA 92: 8729-33

138. Nagano H, Libby P, Taylor MK, Hasegawa S, Stim JL, Becker G, Tilney NL (1998) Coronary arteriosclerosis after T-cell mediated injury in transplanted mouse hearts: role of interferon- $\gamma$. Am J Pathol 152: 1187-1197

139. Nagano H, Mitchell RN, Taylor MK, Hasegawa $S$, Tilney NL, Libby $P$ (1997) Interferon- $\gamma$ deficiency prevents coronary arteriosclerosis but not myocardial rejection in transplanted mouse hearts. J Clin Invest 100: 550-557

140. Nagano H, Tilney NL, Stinn JL, Becker G, Hasegawa S, Libby P, Mitchell RN (1999) Deficiencies of IL-4 or TNF- $\alpha$ R 1 do not diminish graft arteriosclerosis in cardiac allografts. Transplant Proc 31: 152

141. Nakagawa T, Sukhova GK, Rabkin E, Winters GL, Schoen FJ, Libby P (1995) Acute rejection accelerates graft coronary disease in transplanted rabbit hearts. Circulation 92: 987-993

142. Novick AC, Gephardt G, Guz B, Steinmuller D, Tubbs RR (1991) Long-term follow-up after partial removal of a solitary kidney. N Engl J Med 325: 1058-1062

143. O'Grady JG, Alexander GJM, Sutherland S, Donaldson PT, Harvey F, Portmann B, Calne RY, Williams R (1988) Cytomegalovirus infection and donor/recipient HLA antigens: Interdependent co-factors in pathogenesis of vanishing bile duct syndrome after liver transplantation. Lancet 2 : 302-305

144. O'Malley KS, Cook DJ, Flechner SM, McCarthy JF, Klingman LL, Modlin CS, Goldfarb DA, Dennis VW, Novick AC (1998) HLA-antibody production correlates strongly with chronic renal allograft rejection. Abstract XVII World Congress Transplantation Society, Montreal

145. Ojo AO, Wolfe RA, Held PJ, Port FK, Schmouder RL (1997) Delayed graft function: risk factors and implications for renal allograft survival. Transplantation 63: 968-974 
146. Opelz G for the Collaborative Transplant Study (1997) Chronic graft loss in kidney and heart transplant recipients. In: Touraine JL, Traeger J, Bétuel H, Dubernaed JM, Revillard JP, Dupuy C (eds) Late graft loss, Kluwer Academic, London, pp 3-12

147. Opelz G, for the Collaborative transplant study (1997) Critical evaluation of the association between acute and chronic graft rejection in kidney and heart transplant recipients. Transplant proc 29: 73-76

148. Opelz G, Wujciak T, Ritz E (1998) Association of chronic kidney graft failure with recipient blood pressure. Collaborative Transplant Study. Kidney Int 53: 217-222

149. Paul LC, Baldwin WM, Van Es LA (1985) Vascular endothelial alloantigens in renal transplantaton. Transplantation 40: 117-123

150. Paul LC, Hayry P, Foegh M, Dennis MJ, Mihatsch M, Larsson E, Fellström B (1993) Diagnostic criteria for chronic rejection/accelerated graft atherosclerosis in heart and kidney transplants: Proposal from the Fourth Alexis Carrel Conference on Chronic rejection and accelerated arteriosclerosis in transplanted organs. Transplant Proc 25: 2020-2021

151. Paul LC, Muralidharan J, Muzaffar SA, Manting EH, Valentin JF, de Heer E, Kashgarian M (1998) Antibodies against mesangial cells and their secretory products in chronic renal allograft rejection in the rat. Am J Pathol 152: 1209-1223

152. Paul LC, Saito K, Davidoff A, Benediktsson H (1996) Growth factor transcripts in rat renal transplants. Am J Kidney Dis 28: $441-450$

153. Peters TG, Shaver TRS, Ames JE 4th, Santiago-Delphin EA, Jones KW, Blanton JW (1995) Cold ischemia and outcome in 17937 cadaveric kidney transplants. Transplantation 59: 191-196

154. Petrossian GA, Nichols AB, Marboe CC, Sciacca R, Rose EA, Smith CR, Cannon PJ, Reemtsma K, Powers ER (1989) Relation between survival and development of coronary disease and anti-HLA antibodies after cardiac transplantation. Circulation 80 : 122-125

155. Pirsch JD, Ploeg RJ, Gange S, D'Alessandro AM, Knechtle SJ, Sollinger HW, Kalayoglu M, Belzer FO (1996) Determinants of graft survival after renal transplantation. Transplantation 61: 1581-1586
156. Pober JS, Gimbrone MA, Lapierre LA, Mendrick DL, Fiers W, Rothlein R, Springer TA (1986) Overlapping patterns of activation of human endothelial cells by interleukin-1, tumor necrosis factor, and immune interferon. J Immunol 137: 1893-1896

157. Ponticelli C, Mantaginino G, Aroldi A, Angelini C, Braga M, Tarantino A (1993) Hypertension after renal transplantation. Am J Kidney Dis 21:S73-78

158. Porter KA, Owen K, Mowbray JF, Thomson WB, Kenyon JR, Peart WS (1963) Obliterative vascular changes in four human kidney homotrans plants. Br Med J 14: 639-651

159. Poston RS Jr, Billingham ME, Pollard J, Hoyt EG, Robbins RC (1997) Effects of increased ICAM-1 on reperfusion injury and chronic graft vascular disease. Ann Thorac Surg 64: 1004-12

160. Pratschke J, Kusaka M, Wilhelm MJ, Hancock WW, Tilney NL (1999) Acute rejection of rat renal allografts is accelerated by donor brain death. Transplant Proc 31: 874-875

161. Pratschke J, Wilhelm MJ, Kusaka M, Hancock WW, Tilney NL (1999) Activation of proinflammatory genes in somatic organs as a consequence of brain death. Transplant Proc 31: 1003-1005

162. Radovancevic B, Poindexter S, Birovljev S, Velebit V, McAllister HA, Duncan JM, Vega D, Lonquist J, Burnett CM, Frazier OH (1990) Risk factors for the development of accelerated coronary artery disease in cardiac transplant recipients. Eur J Cardiothorac Surg 4: 309-312

163. Raine AEG (1995) Does antihypertenisve therapy modify chronic allograft failure? Kidney Int 48:S107-111

164. Ratner LE, Cigarroa FG, Bender JS, Magnuson T, Kraus ES (1997) Transplantation of single and paired pediatric kidneys into adult recipients. J Am Coll Surg 185: 437-445

165. Reed EF, Hong B, Ho E, Harris PE, Weinberger J, Suciu-Foca N (1996) Monitoring of soluble HLA alloantigens and anti-HLA antibodies identifies heart allograft recipients at risk of transplant-associated coronary disease. Transplantation 61: 566-572

166. Reichenspurner H, Girgis RE, Robbins RC, Yun KL, Nitschke M, Berry GJ, Morris RE, Theodore J, Reitz BA (1996) Stanford experience with obliterative bronchiolitis after lung and heart-lung transplantation. Ann Thorac Surg 62: 1467-1472
167. Rice GE, Bevilacqua MP (1989) An inducible endothelial cell surface glycoprotein mediates melanoma adhesion. Science 246: 1303-1306

168. Rose EA, Pepino P, Barr ML, Smith CR, Ratner AJ, Ho E, Berger C (1992) Relation of HLA antibodies and graft atherosclerosis in human cardiac transplant recipients. J Heart Lung Transplant 11:S120-23

169. Ross R (1993) The pathogenesis of atherosclerosis: a perspective for 1990 s. Nature 362: 801-809

170. Rossen RD, Butler WT, Reisberg MA, Brooks DK, Leachman RD, Milam JD, Mittal KK, Montgomery JR, Nova JJ, Rochelle DG (1971) Immunofluorescent localization of buman immunoglobulin in tissues from cardiac allograft recipients. J Immunol 106: 171-180

171. Russell ME, Hancock WW, Akalin E, Wallace AF, Glysing-Jensen T, Willett TA, Sayegh MH (1996) Chronic cardiac rejection in the Lew to F344 rat model. Blockade of CD28-B7 costimulation by CTLA4Ig modulates T cell and macrophage activation and attenuates arteriosclerosis. J Clin Invest 97: 833-838

172. Russell ME, Wallace AF, Hancock WW, Sayegh MH, Adams DH, Sibinga NE, Wyner LR, Karnovsky MJ (1995) Upregulation of cytokines associated with macrophage activation in the Lewis-to-F344 rat transplantation model of chronic cardiac rejection. Transplantation 59: 572-578

173. Russell PS, Chase CM, Colvin RB (1997) Alloantibody- and T cell-mediated immunity in the pathogenesis of transplant arteriosclerosis: lack of progression to sclerotic lesions in B celldeficient mice. Transplantation 64: 1531-1536

174. Russell PS, Chase CM, Winn HJ, Colvin RB (1994) Coronary atherosclerosis in transplanted mouse hearts. II. Importance of humoral immunity. J Immunol 152: 5135-5141

175. Saito S, Motomura N, Lou H, Ramwell PW, Foegh ML (1997) Specific effects of oestrogen on growth factors and MHC class II expression in rat aorta allograft. $\mathrm{J}$ Thorac Cardiovasc Surg 114: 803-10

176. Salamon RN, Hughes CCW, Schoen FJ, Payne DD, Pober JS, Libby P (1991) Human coronary transplantation-associated arteriosclerosis: evidence for a chronic immune reaction to activated graft endothelial cells. Am J Pathol 138: 791-798 
177. Salomon DR (1991) An alternative view minimizing the significance of cyclosporine nephrotoxicity and in favor of enhanced immunosuppression for long-term kidey transplant recipients. Transplant Proc 23: 2115

178. Schmid C, Heemann U, Tilney NL (1997) Factors contributing to the developement of chronic rejection in heterotopic rat heart transplantation. Transplantation 64: 222-228

179. Schweitzer EJ, Matas AJ, Gillingham K, Payne WD, Gores PF, Dunn DL, Sutherland DER, Najarian JS (1991) Causes of renal allograft loss: progress in the $80 \mathrm{~s}$, challenges for the $90 \mathrm{~s}$. Ann Surg 214: 679-688

180. Scott C, Colquhoun I, Gould K, Au J, Dark J (1992) Determinants of graft arteriosclerosis after heart transplantation. Transplant Int 5:\$238-241

181. Serrick C, La Franchesca S, Giaid A, Shennib H (1995) Cytokine IL-2, TNF $\alpha$ and IFN $\gamma$ release after ischemia reperfusion injury in a novel lung autograft animal model. Am J Respir Crit Care Med 152: 277-282

182. Sharrock CEM, Man S, Wanachiwanawin W, Batchelor JR (1987) Analysis of the T cell repertoire in man. Transplantation 43: 699-703

183. Shi C, Feinberg MW, Zhang D, Patel A, Sim CU, Dong ZM, Chapman SM, Gutierrez-Ramos JC, Wagner DD, Sibinga NE, Haber E (1999) Donor MHC and adhesion molecules in transplant arteriosclerosis. J Clin Invest 103: 469-474

184. Shi C, Lee WS, He Q, Zhang D, Fletcher DL Jr, Newell JB, Haber E (1996) Immunologic basis of transplant-associated arteriosclerosis. Proc Natl Acad Sci USA 93: 4051-4056

185. Shihab FS, Yamamoto T, Nast CC, Cohen AH, Noble NA, Gold LI, Border WA (1995) Transforming growth factor $-\beta$ and matrix protein expression in acute and chronic rejection of human renal allografts. J Am Soc Nephrol 6: 286-294

186. Shimura T, Morrison AB (1975) A progressive glomerulosclerosis occurring in partial five-sixth nephrectomized rats. Am J Pathol 79: 95-106

187. Shin YT, Adams DH, Wyner LR, Akalin E, Sayegh MH, Karnovsky MJ (1995) Intrathymic injection of donor splenocytes plus systemic antilymphocyte serum or antilymphocyte serum alone prolongs cardiac allograft survival and inhibits graft arteriosclerosis in the Lewis-to-F344 chronic rejection model. Transplant Proc 27: 2112-2114
188. Shoskes DA, Cecka JM (1998) Deleterious effects of delayed graft function in cadaveric renal transplant recipients independent of acute rejection. Transplantation 66: 1697-1701

189. Shoskes DA, Parfrey NA, Halloran PF (1990) Increased major histocompatibility complex antigen expression in unilateral ischemic acute tubular necrosis in the mouse. Transplantation 49: 201-207

190. Shoskes DA, Wood KJ (1994) Indirect presentation of MHC antigens in transplantation. Immunol Today 15: 32-38

191. Sibley RK (1997) Histopathology of chronic rejection. In: Touraine JL (ed) Late graft loss, Kluwer Academic, London, pp 13-23

192. Smith JD, Danskine AJ, Rose ML, Yacoub MH (1992) Specificity of lymphocytotoxic antibodies formed after cardiac transplantation and correlation with rejection episodes. Transplantation 53: 1358-1362

193. Smith JD, Rose ML, Pomerance A Burke M, Yacoub MH (1995) Reduction of cellular rejection and increase in longer-term survival after heart transplantation after HLA-DR matching. Lancet 346: 1318-1322

194. Soin AS, Rasmussen A, Jamieson NV, Watson CJ, Friend PJ, Wight DG, Calne RY (1995) CsA levels in the early posttransplant period-predictive of chronic rejection in liver transplantation? Transplantation 59: 1119-1123

195. Solez K, Axelsen RA, Benediktsson H,Burdick JF, Cohen AH, Colvin RB, Croker BP, Droz D, Dunnill MS, Halloran PF, et al (1993) International standardization of nomenclature and criteria for the histologic diagnosis of renal allograft rejection: the BANFF working classification of kidney transplant patology. Kidney Int 44: 411-422

196. Solez K (1994) International standardization of criteria for histologic diagnosis of chronic rejection in renal allografts. Clin Transplantation 8: 345-350

197. Springer TA (1995) Traffic signals on endothelium for lymphocyte recirculation and leucocyte emigration. Annu Rev Physiol 57: 827-872

198. Stein-Oakley A, Jablonski P, Tzanidis A, Baxter K, Howden BO, Marshall VC, Thomson NM (1993) Development of chronic injury and nature of interstial infiltrate in a model of chronic renal allograft rejection. Transplantation 56: 1299-1305
199. Stoltenberg RL, Geraghty J, Steele DM, Kennedy E, Hullett DA, Sollinger HW (1995) Inhibition of intimal hyperplasia in rat aortic allografts with cyclosporin. Transplantation 60 : 993-998

200. Strom TB, Roy-Chaudhury P, Manfro $R$, Zheng XX, Nickerson PW, Wood K, Bushell A (1996) The Th1/Th2 paradigm and the allograft response. Curr Opin Immunol 8: 688-693

201. Suciu-Foca N, Reed E, D'Agati VD, Ho E, Cohen DJ, Benvenistry AI, McCabe R, Brensilver JM, King DW, Hardy MA (1991) Soluble HLA antigens, anti-HLA antibodies, and antiidiotypic antibodies in the circulation of renal transplant recipients. Transplantation 51: 593-601

202. Suciu-Foca N, Reed E, Marboe C,Harris P, Yu XP, Sun YK, Ho E, Rose E, Reemstma K, King DW (1991) The role of anti-HLA antibodies in heart transplantation. Transplantation 51: 716-724

203. Sumrani N, Delaney V, Ding ZK, Butt K, Hong J (1990) HLA-identical renal transplants: impact of cyclosporine on intermediate-term survival survival and renal function. Am J Kidney Dis 16: $417-422$

204. Sumrani N, Hong J, Miles A, et al (1996) Posttransplant serum creatinine under the curve predicts renal allograft outcome. Transplant Proc 28: 356-357

205. Sun H, Subbotin V, Chen C, Aitouche A, Valdivia LA, Sayegh MH, Linsley PS, Fung JJ, Starzl TE, Rao AS (1997) Prevention of chronic rejection in mouse aortic allografts by combined treatment with CTLA4-Ig and antiCD40 ligand monoclonal antibody. Transplantation 64: 1838-1843

206. Suthanthiran M (1997) Molecular analyses of human renal allografts: Differential intragraft gene expression during rejection. Kidney Int 58: 15-21

207. Takada M, Chandraker A, Nadeau KC, Sayegh MH, Tilney NL (1997) The role of the B7 costimulatory pathway in experimental ischemia/reperfusion injury. J Clin Invest 100: 1199-1203

208. Takada M, Nadeau KC, Hancock WW, Mackenzie HS, Shaw GD, Waaga AM, Chandraker A, Sayegh MH, Tilney NL (1998) Effects of explosive brain death on cytokine activation of peripheral organs in the rat. Transplantation 65: 1533-1542 
209. Takada M, Nadeau KC, Shaw GD, Marquette KA, Tilney NL (1997) The cytokine-adhesion molecule cascade in ischemia/reperfusion injury of the rat kidney. Inhibition by a soluble P-selectin ligand. J Clin Invest 99: 2682-2690

210. Takada M, Nadeau KC, Shaw GD, Tilney NL (1997) Prevention of late renal changes after initial ischemia/reperfusion injury by blocking early selectin binding. Transplantation 64: $1520-1525$

211. Tanaka H, Sukhova GK, Libby $P$ (1994) Interaction of the allogeneic state and hypercholesterolemia in arterial lesion formation in experimental cardiac allografts. Arterioscler Thromb 14: 734-445

212. Terasaki PI, Cecka JM, Gjertson DW, Takemoto S (1995) High survival rates of kidney transplants from spousal and living unrelated donors. $N$ Engl $J$ Med 333: 333-336

213. Terasaki PI, Yuge J, Cecka JM, Gjertson DW, Takemoto S, Cho Y (1993) Thirty-year trends in clinical kidney transplantation. In: Terasaki PI, Cecka JM (eds) Clinical Transplant 1993. UCLA Tissue Typing Laboratory, Los Angeles, CA, pp 553-562

214. Thorogood J, Van Houwelingen HC, Van Roodt JJ, Zantvoort FA, Schreuder GMT, Persijn GG (1992) Longterm results of kidney transplantation in Eurotransplant. In: Paul LC, Solez K (eds) Organ Transplantation: Long term Results. Marcel Dekker, New York, pp 33-56

215. Thyberg J, Palmberg L, Nilsson J, Ksiazek T, Sjolünd M (1983) Phenotype modulation in primary cultures of arterial smooth muscle cells. Differentiation 25: 156-167

216. Tilney NL, Gavaroy MR, Busch GJ, Strom TB, Graves MJ, Carpenter CB (1979) Rejected human renal allografts: recovery and characteristics of infiltrating cells and antibody. Transplantation 28: $421-426$

217. Troppmann C, Benedetti E, Gruessner RWG, Payne WD, Sutherland DE, Najarian JS, Matas AJ (1995) Retransplantation after renal allograft loss due to noncompliance. Transplantation 59: 467-471
218. Troppmann C, Gillingham KJ, Benedetti E, Almond PS, Gruessner RWG, Najarian JS, Matas AJ (1995) Delayed graft function, acute rejection, and outcome after cadaver renal transplantation. Transplantation 58: 962-968

219. Tullius SG, Hancock WW, Heemann UW, Azuma H, Tilney NL (1994) Reversibility of chronic renal allograft rejection. Critical effect of time after transplantation suggests both host immune dependent and independent phases of progressive injury. Transplantation 58: 93-99

220. Tullius SG, Heemann U, Hancock WW, Azuma H, Tilney NL (1994) Long-term kidney isografts develop functional and morphologic changes that mimic those of chronic allograft rejection. Ann Surg 220: 425-435

221. Tullius SG, Heemann UW, Azuma H (1994) Early ischemic injury leads to long-term functional and morphologic deterioration of naïve rat kidneys and may contribute to changes of chronic allograft rejection. Transplant Proc 26: 2041

222. Van Saase JLCM, Van der Woude FJ, Thorogood J, Hollander AA, van Es LA, Weening JJ, Bockel JM, Bruijn JA (1995) The relation between acute vascular and interstitial renal allograft rejection and subsequent chronic rejection. Transplantation 59: 1280-1285

223. Vanrentergem Y, Peeters J (1997) The impact of acute rejection on the longterm incidence after renal transplantation. In: Touraine JL, et al (eds) Late graft loss. Kluwer Academic, London, pp 85-89

224. Vereerstraeten $P$, Abramowicz D, De Pauw L, Kinnaert P (1997) Absence of deleterious effect on long-term kidney graft survival of rejection episodes with complete functional recovery. Transplantation 63: 1739

225. Wanders A, Akyürek ML, Waltenberger J, Ren ZP, Stafberg C, Funa K, Larsson E, Fellström B (1995) Ischemia-induced transplant arteriosclerosis in the rat. Arterioscl Thromb Vasc Biol 15: 145-155

226. Wasowska B, Wieder KJ, Hancock WW, Zheng XX, berse B, Binder J, Strom TB, Kupiec-Weglinski JW (1996) Cytokine and alloantibody networks in long-term cardiac allografts in rat recipients treated with rapamycin. J Immunol 156: 395-404
227. Weiser MR, Williams JP, Moore FD Jr Kobzik L, Ma M, Hechtman HB, Carroll MC (1996) Reperfusion injury of ischemic skeletal muscle is mediated by natural antibody and complement. J Exp Med 183: 2343-2348

228. Weller A, Isenmann S, Vestweber (1992) Cloning of the mouse endothelial selectins: expression of both E- and $\mathrm{P}$-selectin is inducible by tumor necrosis factor alpha. J Biol Chem 267 : 15176-15183

229. Wilhelm MJ, Pratschke J, Kusaka M, Hancock WW, Tilney NL (1999) Donor brain death affects tempo and intensity of acute rejection of rat cardiac allografts. Transplant Proc 31: 1008-1009

230. Xiao F, Chong A, Shen, Yang J, Short J, Foster P, Sankary H, Jensik S, Mital D, McChesney L et al (1995) Pharmacologically induced regression of chronic transplant rejection. Transplantation 60: 1065-1072

231. Yeung AC, Davis SF, Hauptman PJ, Kobashigawa JA, Mier LW, Valentine HA, Ventura HO, Wiedermann J, Wilensky R (1995) Incidence and progression of transplant coronary artery disease over 1 year: Results of a multicenter trial with use of intravascular ultrasound. J Heart Lung Transplant 14: $215-220$

232. Yilmaz S, Hayry P (1993) The impact of acute episodes of rejection on the generation of chronic rejection in rat renal allografts. Transplantation 56: 1153-1156

233. Yilmaz S, Kallio E, Yilmaz A, Hayry $\mathbf{P}$ (1995) Chronic renal allograft rejection can be predicted by the surface area under the serum creatinine versus time curve. Transpl Proc 27: 927

234. Yilmaz S, Koskinen PK, Kallio E, Bruggeman CA, Hayry PJ, Lemstrom KB (1996) Cytomegalovirus infectionenhanced chronic kidney allograft rejection is linked with intercellular adhesion molecule-1 expression. Kidney Int 50: 526-537

235. Yilmaz S, Pavoonen T, Hayry P. Chronic rejection of rat renal allografts II (1992) The impact of prolonged ischemia time on transplant histology. Transplantation 53: 823-827

236. Zwacka RM, Zhang Y, Halldorson J, Schlossberg H, Dudus L, Engelhardt JF (1997) CD4 + T-lymphocytes mediate ischemia/reperfusion-induced inflammatory responses in mouse liver. J Clin Invest 100: 279-289 